\title{
Student computer attitudes, experience and perceptions about the use of two software applications in Building Engineering
}

\author{
Esther Chiner ${ }^{a *}$ and Victoria E. Garcia-Vera ${ }^{b}$ \\ ${ }^{a}$ Department of Health Psychology, University of Alicante, Spain \\ ${ }^{b}$ Department of Architecture and Building Technology, Universidad Politécnica de Cartagena, \\ Spain
}

\section{Contact Details:}

Esther Chiner

Departamento de Psicología de la Salud. Universidad de Alicante. P.O. Box 99, 03080, Alicante, Spain.

Tel: +34 965909664

*Corresponding author: esther.chiner@ua.es

Victoria E. Garcia-Vera

Department of Architecture and Building Technology, Universidad Politécnica de Cartagena, Pza. del Cronista Isidoro Valverde, Edif. La Milagrosa, 30202, Cartagena, Spain.

Tel: +34868071046

E-mail: victoria.eugenia@upct.es

Chiner, E. y Garcia-Vera, V. E. (2017). Student computer atitudes, experience and perceptions about the use of two software applications in Building Engineering. European Journal of Engineering Education, 42(6), 1455-1466. doi: 10.1080/03043797.2017.1306025 


\section{Abstract}

The purpose of this study was to examine students' computer attitudes and experience, as well as students' perceptions about the use of two specific software applications (Google Drive Spreadsheets and Arquimedes) in the Building Engineering context. The relationships among these variables were also examined. Ninety-two students took part in this study. Results suggest that students hold favourable computer attitudes. Moreover, it was found a significant positive relationship among students' attitudes and their computer experience. Findings also show that students find Arquimedes software more useful and with higher output quality than Google Drive Spreadsheets, while the latter is perceived to be easier to use. Regarding the relationship among students' attitudes towards the use of computers and their perceptions about the use of both software applications, only a significant positive relationship in the case of Arquimedes was found. Findings are discussed in terms of its implications for practice and further research.

Keywords: computer attitudes and perceptions; computer experience; Arquitecture and Building; software applications; Spain

\section{Introduction}

Generally, Information and Communication Technologies (ICT) are considered to be a symbol of social progress and a useful tool in our daily lives as they became part of the everyday routine. In fact, current students do not conceive the university without the Internet and the use of computers. For them, these and other online resources have always been there (Oblinger and Oblinger 2005). We moved from a time when students moderately preferred the use of ICT in the classroom to a time when technology is embedded in students' lives and they "overwhelmingly prefer and have experienced courses with at least some online components" (Dahlstrom and Bichsel 2014, 3). Overall, students' self-perception about their technology competence is high, even though faculties do not usually involve students in more demanding uses of technology related to communication, sharing information, and problem solving (Kaminski, Switzer, and Gloeckner 2009). In this regard, the study carried out by Mengual (2011) found that, although faculty and students assess positively the inclusion of the digital competence in higher education, faculties show more favourable attitudes than students. Inclusion of digital competence in university teaching practice is even more important in 
technical studies, as the professional practice of those studies entails an extensive use of computer programs.

Computers and the Internet are elements that, properly used, can have a positive impact on the educational system. However, no matter how sophisticated the technology is and how useful it is, an effective implementation of that technology depends on users' attitudes. Positive attitudes towards the use of computers determine the use and the acceptance of ICT (OlveraLobo and Benítez-de-Vendrell 2008). Therefore, there has been concern about the study of students' attitudes towards this issue. Before the 1980s, studies regarding students' attitudes towards technology were scarce, due to the limited use of computers. A few years later, when the use of computers started to be extensive, the interest in this field increased and different projects emerged, such as PATT (Pupil's Attitude Toward Technology) developed by Raat and de Vries (1985). PATT is considered to be one of the first and most relevant international projects with regard to attitudes towards technology. Since then, many researchers have applied the definitions and factors used in that study (Yu et al. 2012) and many scales have been developed to measure students' attitudes towards technology (e.g., Allen 1986; Kay 1993; Loy and Gressard 1984; Popovich et al. 1987; Selwyn 1997; Shaft, Sharfman, and Wu 2003; Wilkinson, Robert, and While 2010). However, most of these instruments have focused on the attitudes towards computers in a generic way, with no specification of particular software applications.

The present study intends to overcome this limitation and focuses not only on students' attitudes towards the use of computers as a learning tool, but also on two different software applications that can be used in the Building Engineering (BE) field for specific purposes, such as budgeting and measurement.

\subsection{Attitudes towards the use of computers as a learning tool}

An attitude is a psychological construct, of mental and emotional nature, that it is inherent in every person (Perloff 2014). It can be described as a latent disposition or tendency to respond in a consistently favourable or unfavourable manner with respect to a given object or situation (Fishbein and Ajzen 2010), in our case, with respect to computers. Therefore, the attitudes that an individual holds towards a given technology can determine its use. Some authors support this idea and consider that positive attitudes towards the use of a technology have an impact on people's intentions to use it, and in turn, that usage intentions affect the actual use of a technology (Davis 1989; Davis, Bagozzi, and Warshaw 1989; Šumak, Heričko, and Pušnik 2011). For this reason, research should be carried out to explore students' attitudes towards the use of 
technology as a learning tool. Moreover, understanding students' attitudes will facilitate the design and implementation of teaching programmes that promote students' learning of a particular technology (De Klerk Wolters 1989).

Literature shows that students generally have favourable attitudes towards technology (Dahlstrom and Bichsel 2014), and the same disposition has been found in the educational field (Novo-Corti, Valera-Candamio, and Ramil-Díaz 2013; Huczynskia and Johnstona 2005). The study carried out by Kitchakarn (2015) among undergraduate students in a private university revealed that students have positive attitudes towards the use of computers as a learning tool. These results seem evident as young people have grown up with computers and have a natural affinity with technology. They are apparently able to adopt it with no effort, in contrast to adults who have less technological affinity and literacy (Waycott et al. 2010). In fact, students' familiarity with technology has led them to demand instant access to information, reject lectures and "passive" forms of learning, and expect technology to be embedded in the educational process (Waycott et al. 2010). Other authors, however, think that technology has little influence on students' involvement in certain courses or as a way to communicate with other students and faculty (Dahlstrom and Bichsel 2014).

\subsection{Attitudes and computer experience}

Assuming that there is certain dependence on computers and technology in all the areas of our lives, either for educational, work or recreational purposes, there is the necessity to understand the extent to which computer attitudes are related to individuals' experience with computers. Research literature have tried to establish relationships among both constructs with results that have been, in some cases, inconsistent (e.g., Bozionelos 2001; Drent and Meelisen 2008; Kitchakarn 2015; Topkaya 2010).

Some research suggests that there is a positive relationship between computer attitudes and computer experience. That is, the more contact a person has with computers, it is more likely that he or she will have a favourable attitude towards them (Bozionelos 2001; Smith et al. 1999). Drent and Meelissen (2008) carried out a literature review identifying the factors which positively influence the implementation of ICT in education, such as experience with the computer for educational purposes, positive views to ICT in general, and positive views towards the contribution of ICT to education. The authors selected some of the previously identified factors and analysed their impact on the innovative use of ICT in the teaching practice, understanding this variable as the "use of ICT applications that support the educational 
objectives based on the needs of the current knowledge society" (Drent and Meelissen 2008, 187). The study bears that four factors have a direct positive influence on the innovative use of ICT by teacher educators: a positive ICT attitude, years of computer experience, a studentoriented pedagogical approach, and personal entrepreneurship of the teacher educator. It was also found a relationship between the variables ICT attitude and years of computer experience. Similar results were found in other studies (Mitra 1998; Rex and Roth 1998; Rozell and Gardner 2000; Topkaya 2010) where students' computer-related experiences showed positive relationships with computer use. According to Park and Cho (2014), these studies prove the effect of student's computer experience on their attitudes towards the use of computers in class.

However, other investigations hold that the use and the experience with computers are poor predictors of computer attitudes (Garland and Noyes 2004). Likewise, the study conducted by Kitchakarn (2015) with 192 undergraduate EFL (English as a Foreign Language) students revealed that participants had positive attitudes towards computer-based learning, but experience was found not to be related or have any influence on students' attitudes.

\subsection{Perceptions about the use of software applications in Building Engineering}

According to Richardson (1996), perceptions and attitudes drive individuals' thinking processes, action, and predisposition to change before certain challenges. For this reason, the study of these constructs become determinant to understand users' intentions to use certain technology. Individuals' attitudes and perceptions towards a particular technology are determinant factors when predicting whether or not the individual will use and accept that technology. In this sense, a diverse set of technology acceptance and usage models were developed to explain and predict individuals' use and behavioural intentions when using a particular technology (Davis 1989; Davis, Bagozzi, and Warshaw 1992; Liaw et al. 2006; Liaw and Huang 2003; Venkatesh et al. 2003). These models have been used in different contexts. For instance, the Technology Acceptance Model (TAM), developed by Davis (1989) was designed to predict information technology acceptance and usage on the job, and has been widely applied to a diverse set of technologies and users. Furthermore, TAM's author assures that the results drawn from the application of the model would have a great practical value for vendors, information systems (IS) managers and IS practitioners (Davis 1989; Davis, Bagozzi, and Warshaw 1989). However, TAM has not only been used for commercial purposes, but also for other purposes such as remote patient monitoring system acceptance trends (Giger et al. 2015), the study of search 
engines acceptance as a tool for retrieving information (Liaw and Huang 2003) or as a learning assisted tool (Liaw et al. 2006). Moreover, most of these models have been utilized to evaluate the use of ICT in the educational field, especially in e-learning (Šumak, Heričko, and Pušnik 2011) and m-learning contexts (Huan et al. 2015; Tretiakov and Kinshuk 2008).

The methodological approach of our study considers the variables included in TAM proposed by Davis, Bagozzi, and Warshaw (1992), i.e., perceived usefulness, perceived ease of use, output quality, enjoyment, and behavioural intentions. We define perceived usefulness as the degree to which a person believes that using a particular technology will enhance their performance (Davis 1989). Perceived ease of use is defined in terms of effort, and it is the extent to which a person believes that using a particular technology will be free of effort (Davis 1989; Venkatesh 1999). Based on the definition of Davis, Bagozzi, and Warshaw (1992) we define output quality in terms of a user's value judgement about the perceived quality of intermediate and final products obtained by the use of a particular technology. Enjoyment is the extent to which the activity of using a specific technology is perceived by the user as enjoyable, apart from any performance consequences that may be anticipated (Davis, Bagozzi, and Warshaw 1992). Finally, behavioural intentions is defined as "a person's subjective probability that he or she will perform some behaviour" (Fishbein and Ajzen 1975, 288).

Although TAM analyses the relationship between all these variables to determine how well they predict users' intentions of use and actual use of a particular technology, the purpose of our study is to explore, from a descriptive view, users' perceptions about two software applications to elaborate budgets and measurements in the BE field, taking into account the five dimensions proposed by Davis, Bagozzi, and Warshaw (1992). We intend to know which application is considered to be better for budgeting and measuring purposes and the relationship of users' perceptions about these applications with their attitudes towards the use of computers as a learning tool.

Therefore, the purpose of this study was to investigate students' computer attitudes and experience, as well as their perceptions about the use of two particular software applications in $\mathrm{BE}$. It also aimed to determine the relationships among these variables. Particularly, the study was designed to explore the following objectives:

1. To examine students' attitudes towards the use of computers as a learning tool and the relationship with students' computer experience. 
2. To describe and compare students' perceptions about the use of two software applications to elaborate budgets and measurements in BE (Google Drive Spreadsheets and Arquimedes software).

3. To examine the relationship between students' computer attitudes and students' perceptions about the use of two software applications to elaborate budgets and measurements.

The study aims to obtain deeper knowledge about the nature of attitudes and perceptions regarding the use of computers, and the convenience of two particular tools in the field of $\mathrm{BE}$ education. A better understanding of students' perceptions may shed more light on instructional design and help faculties to choose the best tools for students' learning and professional success.

\section{Method}

\subsection{Participants}

The sample comprised $92 \mathrm{BE}$ students from a Spanish public mid-sized university. A total of 57 students were male (62\%) and 35 were female participants (38\%). Their average age was 23.8 $(S D=3.4)$ and it ranged between 20 and 39. The majority of the participants $(n=88,95.7 \%)$ were taking the course for the first time and about a third combined work and study ( $n=29,31.5 \%$ ). Most of the participants that worked did not have a job related to the subject (96.6\%).

Regarding the use of Internet, $94.6 \%$ of the students $(n=87)$ use it everyday, especially at home $(94.6 \%)$ and at the university $(85.9 \%)$, as well as on their mobile phones $(70.3 \%)$. They mainly use the Internet for learning ( $n=90,97.8 \%)$, leisure ( $n=79,85.9 \%)$, e-mailing and IM ( $n=77$, $83.7 \%$ ), social media ( $n=76,82.6 \%)$, and information search ( $n=65,70.7 \%)$.

Participants reported to have some to moderate computer experience ( $n=75,81.5 \%)$ and experience with spreadsheets ( $n=72,78.2 \%$ ). However, they had little or none experience with collaborative spreadsheets, such as Google Drive $(n=61,67.1 \%)$. When they were asked about specific software applications for building project budgeting, the majority stated to have none experience $(n=73,79.3 \%)$. 


\subsection{Instrumentation}

Participants had to complete a questionnaire which encompassed five sections. The first section included demographic information (e.g., gender, age, work). The second one sought to collect information about students' use of Internet ( 3 items). The third section comprised questions about students' experience with computers and software applications (5 items). Participants had to respond to this section using a five-point Likert scale ( $1=$ none; $5=$ extensive $)$. The fourth section was based on Selwyn's Computer Attitude Scale (1997) and it was used to measure students' attitudes towards the use of computers as a learning tool (21 items). Finally, the 16 statements of the last section were drawn from the scale developed by Davis, Bagozzi and Warshaw (1992) concerning students' perceptions of use of two specific software applications for budgeting and measurement purposes (Google Drive Spreadsheets and Arquimedes software). Items on this section were organised in five dimensions: (a) perceived usefulness (4 items), (b) enjoyment ( 3 items), (c) perceived ease of use ( 4 items), (d) perceived output quality ( 3 items), and (e) usage intentions ( 2 items). This section was administered twice: once to collect information about students' perceptions on Google Drive Spreadsheets and the second time to get information about Arquimedes software. Sections 4 and 5 comprised five-point Likert scales where respondents had to indicate their level of agreement with each item $(1=$ strongly disagree; 5 = strongly agree) .

The instrument as a whole showed a good internal consistency, as measured by the Cronbach's Alpha coefficient, of .87 for the Arquimedes software version and of .82 for the Google Drive Spreadsheets version. Cronbach's Alpha coefficients for each section of the instrument were of .67 for the five items regarding experience, .77 for the computer attitudes section, and .92 for both Google Drive Spreadsheets and Arquimedes subscales.

\subsection{Procedure}

Students participated in the course Economic management: measurements, budgets, and property valuations offered in the third year of the Building Engineering degree. The first half of the course was devoted to working with Google Drive Spreadsheets since small building companies often use spreadsheets. Afterwards, they were asked to complete the instrument anonymously and voluntarily. It included the five sections aforementioned, but the fifth section alluded exclusively to students' perceptions about Google Drive Spreadsheets. The compilation of the questionnaire lasted approximately 15-20 minutes. During the second half of the course, students worked with the Arquimedes software (http://arquimedes.en.cype.com/). Arquimedes 
is a specialised software application widely used in Spain by medium and large companies for project management in the fields of Architecture, Engineering and Construction (e.g., measurements, budgets, specifications and project certifications). By the end of the course, participants had to respond again to section 5 of the instrument which referred, in this case, to students' perceptions about the use of Arquimedes software for budgeting and measurement purposes. Students completed the questionnaire in approximately 5-8 minutes.

\subsection{Data analysis}

Descriptive measures were carried out to analyse the data collected (e.g., means, standard deviations, and percentages). Differences between the two software applications were analysed using the Wilcoxon Signed Rank Test and the Paired-Samples t-test. Finally, the Pearson productmoment correlation coefficient was used to examine the relationships among attitudes, computer experience and perceptions.

\section{Results}

\subsection{Student computer attitudes and the relationship with computer experience}

A total score was created out of the 21 statements regarding computer attitudes (maximum = 105). Overall, students show positive attitudes towards the use of computers as a university learning tool with an average score of 85.54 (range 43-101, $S D=8.89$ ). As shown in Table 1, most of the students (81.6\%) think that computers help them to organise their work better, and that computers can allow them to do more interesting and imaginative work (83.7\%). They do not feel apprehensive $(82.6 \%)$ or scared $(84.8 \%)$ about using a computer. They also state that, when they get problems using the computer, they can usually solve them one way or the other (72.9\%). On the other hand, only $3.3 \%$ of the participants report that they would avoid taking a job if they knew it involved working with computers, and the same percentage state that they are not in complete control when they use a computer. Data also showed that $13.1 \%$ of the students only use computer in college when told to and $8.7 \%$ avoid coming into contact with computers in that context. Finally, $5.4 \%$ of the participants say that computers make them feel uncomfortable and $4.4 \%$ hesitate to use a computer for fear of making mistakes that they cannot correct. 
Table 1. Students' attitudes towards the use of computers as a learning tool

\begin{tabular}{|c|c|c|c|c|c|c|}
\hline & & \multicolumn{3}{|r|}{ SD / D } & \multirow{2}{*}{$\frac{U}{\%}$} & \multirow{2}{*}{$\frac{\mathrm{A} / \mathrm{SA}}{\%}$} \\
\hline & & $M$ & $S D$ & $\%$ & & \\
\hline 1. & $\begin{array}{l}\text { If given the opportunity to use a computer I am } \\
\text { afraid that I might damage it in some way. }\end{array}$ & 1.82 & 1.16 & 80.4 & 7.6 & 11.9 \\
\hline 2. & Computers help me to organise my work better. & 4.20 & 0.94 & 5.5 & 13 & 81.6 \\
\hline 3. & $\begin{array}{l}\text { I could probably teach myself most of the things I } \\
\text { need to know about computers. }\end{array}$ & 3.08 & 1.07 & 31.5 & 28.3 & 40.2 \\
\hline 4. & $\begin{array}{l}\text { I would avoid taking a job if I knew it involved } \\
\text { working with computers. }\end{array}$ & 1.34 & 0.82 & 93.4 & 3.3 & 3.3 \\
\hline 5. & I hesitate to use a computer in case I look stupid. & 1.64 & 0.94 & 82.6 & 13 & 4.4 \\
\hline 6. & $\begin{array}{l}\text { Computers can enhance the presentation of my } \\
\text { work to a degree which justifies the extra effort. }\end{array}$ & 4.43 & 0.97 & 6.5 & 2.2 & 91.3 \\
\hline 7. & $\begin{array}{l}\text { I am not in complete control when I use a } \\
\text { computer. }\end{array}$ & 1.72 & 0.77 & 87 & 9.8 & 3.3 \\
\hline 8. & I don't feel apprehensive about using a computer. & 4.28 & 1.13 & 9.7 & 7.6 & 82.6 \\
\hline & I can make the computer do what I want it to do. & 3.41 & 0.93 & 14.2 & 41.3 & 44.5 \\
\hline 10. & I only use computer in college when told to. & 1.86 & 1.09 & 79.3 & 7.6 & 13.1 \\
\hline & $\begin{array}{l}\text { I need an experienced person nearby when I use a } \\
\text { computer. }\end{array}$ & 1.73 & 1.00 & 83.6 & 7.6 & 8.7 \\
\hline & Using a computer does not scare me at all. & 4.32 & 1.11 & 9.7 & 5.4 & 84.8 \\
\hline & $\begin{array}{l}\text { Most things that a computer can be used for I can } \\
\text { do just as well myself. }\end{array}$ & 2.86 & 1.07 & 38.1 & 32.6 & 29.3 \\
\hline & $\begin{array}{l}\text { I avoid coming into contact with computers in } \\
\text { college. }\end{array}$ & 1.76 & 0.97 & 82.6 & 8.7 & 8.7 \\
\hline & $\begin{array}{l}\text { If I get problems using the computer, I can usually } \\
\text { solve them one way or the other. }\end{array}$ & 3.87 & 1.00 & 8.6 & 18.5 & 72.9 \\
\hline & $\begin{array}{l}\text { I hesitate to use a computer for fear of making } \\
\text { mistakes I can't correct. }\end{array}$ & 1.79 & 0.89 & 80.5 & 15.2 & 4.4 \\
\hline & $\begin{array}{l}\text { Computers can allow me to do more interesting } \\
\text { and imaginative work. }\end{array}$ & 4.14 & 1.00 & 8.7 & 7.6 & 83.7 \\
\hline & I will use computers regularly throughout college. & 4.35 & 0.96 & 7.6 & 2.2 & 90.2 \\
\hline & $\begin{array}{l}\text { I do not need somebody to tell me the best way to } \\
\text { use a computer. }\end{array}$ & 2.93 & 1.14 & 37 & 31.5 & 31.5 \\
\hline & Computers make me feel uncomfortable. & 1.43 & 0.84 & 91.3 & 3.3 & 5.4 \\
\hline & $\begin{array}{l}\text { Computers make it possible to work more } \\
\text { productively. }\end{array}$ & 4.48 & 0.85 & 4.4 & 4.3 & 91.3 \\
\hline
\end{tabular}

Note: $\mathrm{SD}=$ Strongly disagree; $\mathrm{D}=$ Disagree; $\mathrm{U}=$ Undecided; $\mathrm{A}=$ Agree; $\mathrm{SA}=$ Strongly agree

To examine the relationship between the overall computer attitude score and the students' computer experience, a Pearson product-moment correlation coefficient was conducted. Results showed a moderate and significant positive relationship among the variables $(r=.43, N$ 
$=92, p=.000)$ which indicates that positive attitudes towards the use of computers is related to higher computer experience.

\subsection{Differences on students' perceptions about the use of two software applications to} elaborate budgets and measurements

In order to simplify data, responses to the 5-point Likert scale were recoded into a new variable with only three categories: $1=$ Disagree $; 2=$ Undecided; $3=$ Agree. Table 2 shows descriptives for participants' perceptions about the use of Google Drive Spreadsheets and the Arquimedes software to prepare budgets and measurements in $\mathrm{BE}$, as well as differences on perceptions among the two applications by using the Wilcoxon Signed Rank Test.

Table 2. Differences on students' perceptions about the use of Google Drive Spreadsheet and Arquimedes

\begin{tabular}{|c|c|c|c|c|c|}
\hline \multicolumn{6}{|c|}{ Google Drive } \\
\hline D & $U$ & A & D & $U$ & A \\
\hline$\%$ & $\%$ & $\%$ & $\%$ & $\%$ & $\%$ \\
\hline
\end{tabular}

\section{Perceived usefulness}

1. Using GD/Arquimedes software would improve my performance in my professional practice.

2. Using GD/Arquimedes software would increase my professional productivity.

3. Using GD/Arquimedes software would enhance my professional effectiveness.

4. I would find GD/Arquimedes software useful in my professional practice.

Enjoyment

5. I would find using GD/Arquimedes software to be enjoyable in my professional practice.

6. Using GD/Arquimedes software would be pleasant in my professional practice.

7. I would have fun using GD/Arquimedes software in my professional practice.

Perceived ease of use

8. Learning to operate GD/Arquimedes software would be easy for me.

$\begin{array}{ccccccccc}8.7 & 27 . & 64.2 & 4.4 & 22.8 & 72.8 & 1.468 & .142 & .10 \\ & 1 & & & & & & & \\ 10 . & 28 . & 60.9 & 3.3 & 20.7 & 76.0 & 2.447 & .014 & .18 \\ 9 & 2 & & & & & & & \\ 11 . & 28 . & 59.8 & 3.3 & 27.2 & 69.6 & 1.999 & .046 & .14 \\ 9 & 3 & & & & & & & \\ 9.8 & 23 . & 66.3 & 3.3 & 17.3 & 79.4 & 2.097 & .036 & .15\end{array}$

20. 32.

$7 \quad 5$

46.8

12.

43.5

$44.5 \quad 0.596$

.551

.04

11. 29 .

93

19. 35 .

68

58.8

13.0

31.5

$55.5-0.397$

.691

.02

44.6

18.5

41.3

40.2

$-0.185$

$.854 \quad .01$

\section{1}

8.7

89.2

26.

32.6

$41.3 \quad-5.770$

.000

9. I would find it easy to get GD/Arquimedes software to do what I want it to do.

$1.1 \quad 10$.

88.0

17.4

29.3

53.3

$-4.869$

.000 .36

10. It would be easy for me to become skilful at using GD/Arquimedes software. easy to use.

$\begin{array}{lllllllll}1.1 & 8.7 & 90.2 & 10.9 & 29.3 & 59.8 & -4.701 & .000 & .34\end{array}$




\section{Output quality}

12. Assuming I were to use GD/Arquimedes software for professional purposes, the quality of the output I would get would 15. 34 be high.

13. Using GD/Arquimedes software for professional purposes, the effectiveness of the finished product would be high.

14. Using GD/Arquimedes software for professional purposes, the final output would be professional looking.

$\begin{array}{ccccccccc}15 . & 34 . & 50.0 & 3.3 & 20.7 & 76.0 & 3.488 & .000 & .25\end{array}$

$\begin{array}{ccccccccc}5.5 & \begin{array}{c}25 . \\ 0\end{array} & 69.5 & 2.2 & 15.2 & 82.6 & 1.938 & .053 & .14 \\ & & & & & & & & \\ 16 . & 27 . & 56.5 & 2.2 & 19.6 & 78.2 & 3.414 & .001 & .25 \\ 3 & 2 & & & & & & & \end{array}$

Behavioural intentions

15. Assuming GD/Arquimedes software would be available on my job, I predict that I would use it on a regular basis in the future.

16. It is likely I will use GD/Arquimedes software in my professional practice.

\begin{tabular}{ccccccccc}
9.8 & $\begin{array}{c}30 . \\
4\end{array}$ & 59.8 & 7.6 & 21.8 & 70.6 & 1.202 & .229 & .08 \\
11. & 26. & 62.0 & 7.6 & 17.4 & 75.0 & 1.496 & .135 & .11 \\
9 & 1 & & & & & & & \\
\hline
\end{tabular}

Note: $D$ = Disagree; $U$ = Undecided; $A=$ Agree

Regarding Perceived usefulness, the majority of the students considered that both applications would be useful in their professional practice. However, responses were higher with respect to the Arquimedes software. In fact, $76 \%$ of the participants thought that Arquimedes would increase their professional productivity, as against $60.9 \%$ for Google Drive Spreadsheets ( $Z=$ 2.447, $p<.05)$, although the effect size was small $(r=.18)$. They also thought that Arquimedes would be more effective than Google Drive Spreadsheets (69.6\% vs 59.8\%, Z=1.999, $p<.05)$, as well as more useful $(79.4 \%$ vs $66.3 \%, Z=2.097, p<.05)$. Again, effect sizes were small in both cases $(r=.14$ and $r=.15$, respectively). These results were confirmed with a paired-samples ttest to examine differences on the dimension perceived usefulness. As shown in Table 3, there was a statistically significant difference between Google Drive Spreadsheets $(M=14.52, S D=$ 3.28) and Arquimedes $(M=15.64, S D=2.81), t(91)=-2.358, p<.05$, with a small effect size $(r=$ .24).

Table 3. Differences on students' perceptions about the use of Google Drive Spreadsheet and Arquimedes

\begin{tabular}{|c|c|c|c|c|c|c|c|c|}
\hline & \multicolumn{2}{|c|}{ Google Drive } & \multicolumn{2}{|c|}{ Arquimedes } & \multirow[b]{2}{*}{$t$} & \multirow[b]{2}{*}{$d f$} & \multirow[b]{2}{*}{$p$} & \multirow[b]{2}{*}{$r$} \\
\hline & $M$ & $S D$ & $M$ & $S D$ & & & & \\
\hline Perceived usefulness & 14.52 & 3.28 & 15.64 & 2.81 & -2.358 & 91 & .021 & .24 \\
\hline Enjoyment & 10.13 & 2.74 & 10.11 & 2.39 & .049 & 91 & .961 & .00 \\
\hline Perceived ease of use & 16.82 & 2.31 & 13.66 & 3.06 & 8.461 & 91 & .000 & .66 \\
\hline Output quality & 10.61 & 2.51 & 11.95 & 1.92 & -3.746 & 91 & .000 & .36 \\
\hline Behavioural intentions & 7.27 & 1.91 & 7.74 & 1.77 & -1.552 & 91 & .124 & .16 \\
\hline
\end{tabular}


With respect to Enjoyment, no statistically significant differences were found between the use of Google Drive Spreadsheets $(M=10.13, S D=2.74)$ and the Arquimedes software $(M=10.11$, $S D=2.39), t(91)=.049, p>.05$. Participants evaluated both applications as moderately enjoyable in their professional practices with percentages around $50 \%$.

As for Perceived ease of use, participants clearly considered Google Drive Spreadsheets $(M=$ $16.82, S D=2.31)$ easier to use than the Arquimedes software $(M=13.66, S D=3.06)$, with statistically significant differences between them $[t(91)=8.461, p<.01]$ and a large effect size $(r=.66)$. For instance, $89.2 \%$ of the participants thought that it would easy for them to learn to operate Google Drive Spreadsheets and only $41.3 \%$ thought the same for Arquimedes ( $Z=-$ $5.770, p<.01$ ). Also, $80.4 \%$ considered that it would be easy for them to become skillful at using Google Drive Spreadsheets. When they were asked this same question regarding Arquimedes software, the percentage dropped to $53.3 \%(Z=-4.215, p<.01)$. Statistically significant differences were found in all the items of this dimension with a medium effect size for all of them (see Table 2 above).

Concerning Output quality, participant students perceived Arquimedes software to be higher ( $M$ $=11.95, S D=-3.746)$ than Google Drive Spreadsheets $(M=10.61, S D=2.51), t(91)=-3.746, p<$ .01. The effect size in this case was moderate $(r=.36)$. Assuming they were to use these applications for professional purposes, $76 \%$ of the participants thought that the quality of the output they would get with the Arquimedes software would be high, while only $50 \%$ of the participants agreed with this statement regarding Google Drive Spreadsheets $(Z=3.488, p<.01$, $r=.25)$. Also, the final output would be more professional looking with the Arquimedes software than with the Google Drive Spreadsheets (78.2\% vs 56.5\%, $Z=3.414, p<.01, r=.25$ ).

Finally, in regard to Behavioural intentions, no significant differences were found between Google Drive Spreadsheets $(M=7.27, S D 1.91)$ and Arquimedes $(M=7.74, S D=1.77), t(91)=-$ $1.552, p>.05)$. However, participants were more likely to use Arquimedes (75\%) than Google Drive Spreadsheets (62\%) in their professional practice.

\subsection{Relationship between student computer attitudes and perceptions about the use of two software applications}

A series of Pearson product-moment correlation coefficients were carried out to examine the relationship between students' attitudes towards the use of computers to support learning and their perceptions about the use of two software applications to elaborate budgets and 
measurements (Table 4). As for Google Drive Spreadsheets, a statistically significant relationships was found between attitudes and enjoyment $(r=-.206, N=92, p=.049)$, suggesting that more positive attitudes towards the use of computers to support learning are related to lower enjoyment of the application. On the other hand, there was also a significant, but positive, relationship between attitudes and perceived ease of use $(r=.223, N=92, p=.032)$, suggesting that those students with better attitudes perceived Google Drive Spreadsheets easier to use. Nevertheless, despite the significance of these relationships, they were low. Regarding Arquimedes software, a statistically significant relationship was found only between attitudes and the total score of the perceptions scale $(r=.248, N=92, p=.017)$, suggesting that students with more positive attitudes towards the use of computers as a learning tool also have more favourable perceptions about the use of the Arquimedes software for budgeting and measurement in $\mathrm{BE}$.

Table 4. Relationship between computer attitudes and perceptions about the use of Google Drive Spreadsheet/Arquimedes

\begin{tabular}{lcc}
\hline & \multicolumn{1}{c}{ Google Drive Spreadsheets } & Arquimedes \\
\cline { 2 - 3 } & $\boldsymbol{r}$ & $\boldsymbol{r}$ \\
\hline Attitudes & & \\
Perceived usefulness & -.065 & .179 \\
Enjoyment & $-.206^{*}$ & .202 \\
Perceived ease of use & $.223^{*}$ & .193 \\
Output quality & -.040 & .183 \\
Behavioural intentions & -.022 & .205 \\
Total scale & -.042 & $.248^{*}$ \\
\hline
\end{tabular}

\section{Discussion}

The purpose of this study was to explore BE students' attitudes towards computer use as a learning tool and their perceptions about the use of two software applications. Results suggest that, overall, students hold favourable attitudes towards the use of computers to support their learning at the university. Similar findings were found in previous studies in the educational context where students also have positive attitudes towards the use of computers as a learning tool (e.g., Kitchakarn 2015; Novo-Corti, Valera-Candamio, and Ramil-Díaz 2013). These findings seem reasonable considering that, nowadays, computers are embedded in all facets of our daily lives, and that students do not conceive the university without the use of the Internet and 
computers. Students accept the use of computers, expect it, and feel more engaged and involved when using them in class as part of the learning process (Zweekhorst and Maas 2015). Regarding the relationship between computer attitudes and experience with computers, research literature shows inconclusive findings. While some studies maintain that there is no relationship between both variables (Garland and Noyes 2004; Kitchakarn 2015), others show evidence about this relationship (Bozionelos 2001; Drent and Meelissen 2008; Topkaya 2010). Consistent with the second trend, we found a statistically significant positive relationship between students' attitudes towards the use of computers and their experience with them. We expect that the more contact users have with computers, the more likely it is that they have favourable attitudes towards them. Laptops, tablets, and smartphones are part of current university students. They use these devices for all kind of activities (e.g., learning, socializing, searching information) and, therefore, we can expect that they have an extensive computer experience and a favourable disposition to use it.

The aim of this study was also to explore the use in class of two software applications to learn how to elaborate budgets and measurements in the field of BE. Students' perceptions in terms of usefulness, enjoyment, ease of use, output quality, and behavioural intentions of use for professional purposes of both tools were analysed and compared. Findings show significant differences in students' perceptions when comparing both applications (Google Drive Spreadsheet and Arquimedes). Students find Arquimedes software more useful and with higher output quality than Google Drive Spreadsheets, while the latter is perceived to be easier to use. These results suggest the importance of implementing software programs in class that fulfill, at least, these three features: usefulness, output quality and ease of use. Students will be more likely to use a particular application, both in class and in professional settings, when it meets these requirements.

Finally, the relationship between students' attitudes towards the use of computers to support learning and their perceptions about the use of both software applications were analysed. Regarding Arquimedes software, students with more favourable attitudes towards the use of computers also showed more favourable perceptions about the use of this software application. This relationship was found only for the total scale (in terms of perceived usefulness, enjoyment, perceived ease of use, output quality and behavioural intentions). However, concerning Google Drive Spreadsheets, no significant relationships were found neither for the total scale nor for each of the dimensions. In light of these results, we may expect that students with better 
attitudes towards the use of computers prefer more specialised programs, such as Arquimedes, to be used both in class and for professional purposes.

Despite this study was conducted rigorously, some limitations must be considered and addressed in future research. First, findings from this study were drawn from students of a particular university and may not reflect the students' attitudes and perceptions from other universities. Future research could include other universities in order to replicate and validate findings. Second, responses to this study were voluntary and relied on students self-reported data. Therefore, results may be biased by socially desirable responses. Third, attitudes, experience and perceptions were measured at a single point in time. Future research should include longitudinal studies to evaluate variable changes over time.

\section{Conclusions}

This study shows that students hold positive attitudes towards the use of computers and that these attitudes are related to students' experience with computers and with their perceptions about the two software applications used in class to elaborate budgets and measures in the field of Building Engineering (Arquimedes software and Google Drive Spreadsheets). The study also shows that students' perceptions, in terms of perceived usefulness, enjoyment, perceived ease of use, output quality and behavioural intentions of use, of two different software applications may vary. To know individuals' attitudes and perceptions about a particular technology is crucial as they determine the use and acceptance of that technology. In addition, a better understanding of these factors will guide professionals who wish to implement successfully a particular technology in academic or professional contexts. In other words, when we want to implement tools that are going to be used by other persons (for instance, students or employees), we must take into account which applications are more appreciated by individuals in order to obtain more success rates when implementing them.

On the other hand, assuming that the two software applications employed in this study were to be used for professional purposes, Arquimedes is perceived to be more useful and with higher output quality than Google Drive Spreadsheets, while the latter is perceived to be easier to use. These results are reasonable as Arquimedes is a specific application program to elaborate budgets and measurements in Engineering. Google Drive Spreadsheets, however, is a generic tool that needs to be previously customized to gain professional output quality. Besides, it may be too complex to elaborate major projects with this tool. These findings suggest that if universities want to prepare competitive individuals that will soon access the labour market, 
they should include specific applications in their teaching practice that are more probably to be used later in the professional context. University contents and labour market should be interconnected in a way that students learn how to use certain tools that are going to be useful in their professional practice. In this regard, further research should be conducted in order to evaluate the quality and usefulness of software applications not only for learning purposes but also for professional purposes.

\section{References}

Allen, Lois R. 1986. “Measuring attitude toward computer assisted instruction: Development of a semantic differential tool." Computers in Nursing 4 (4): 144-151.

Bozionelos, Nikos. 2001. "Computer anxiety: Relationship with computer experience and prevalence." Computers in Human Behavior, 17 (2): 213-224. doi:10.1016/S0747$5632(00) 00039-X$

Dahlstrom, Eden, and Jacqueline Bichsel. 2014. "ECAR Study of Undergraduate Students and Information Technology." Accessed $06 \quad$ April 2016. http://www.csus.edu/irt/cio/strategicplanning/Documents/Undergrad-Studentsand-IT-2014-Full-Report.pdf

Davis, Fred. D. 1989. "Perceived usefulness, perceived ease of use, and user acceptance of information technology." MIS Quarterly 13 (3): 319-340. doi: http://dx.doi.org/10.2307/249008.

Davis, Fred D., Richard P. Bagozzi, and Paul R. Warshaw. 1989. "User acceptance of computer technology: A comparison of two theoretical models." Management Science 35 (8): 982-1003. doi: http://dx.doi.org/10.1287/mnsc.35.8.982.

Davis, Fred D., Richard P. Bagozzi, and Paul R. Warshaw. 1992. "Extrinsic and intrinsic motivation to use computers in the workplace." Journal of Applied Social Psychology 32 14: 11111132. doi: http://dx.doi.org/10.1111/j.1559-1816.1992.tb00945.x.

de Klerk Wolter, Falco. 1989. The attitude of pupils towards technology. Eindhoven: Eindhoven University of Technology. 
Drent, Marjolein, and Martina Meelissen. 2008. "Which factors obstruct or stimulate teacher educators to use ICT innovatively?" Computers \& Education 51 (1): 187-199. doi>10.1016/j.compedu.2007.05.001.

Fishbein, Martin, and Icek Ajzen. 1975. Belief, attitude, intention, and behavior: An introduction to theory and research. Reading, MA: Addison-Wesley.

Fishbein, Martin, and Icek Ajzen. 2010. Predicting and Changing Behavior. The reasoned Action Approach. New York, NY: Psychology Press.

Garland, Kate J., and Jan M. Noyes. 2004. “Computer experience: a poor predictor of computer attitudes." Computers in Human Behavior 20 (6): 823-840. doi: 10.1016/j.chb.2003.11.010.

Giger, Jarod T., Natalie D. Pope, H. Bruce Vogt, Cassity Gutierrez, Lisa A. Newland, Jason Lemke, and Michael J. Lawler. 2015. "Remote patient monitoring acceptance trends among older adults residing in a frontier state." Computers in Human Behavior 44: 174-182. doi:10.1016/j.chb.2014.11.044.

Huan, Yu Xueping Li, Mehmet Aydeiz, and Tami Wyatt. 2015. "Mobile Learning Adoption: An Empirical Investigation for Engineering Education." International Journal of Engineering Education 31 (4): 1081-1091.

Huczynskia, Andrzej, and Scott P. Johnston. 2005. "Engineering students' use of computer assisted learning (CAL)." European Journal of Engineering Education 30 (2): 287-298. doi: 10.1080/03043790500087530.

Kaminski, Karen, Jamie Switzer, and Gene Gloeckner. 2009. "Workforce readiness: A study of university students' fluency with information technology." Computers \& Education 53 (2), 228-233. doi:10.1016/j.compedu.2009.01.017.

Kay, Robin H. 1993. "An exploration of theoretical and practical foundations for assessing attitudes toward computers: the Computer Attitude Measure (CAM)." Computers in human behavior 9 (4): 371-386. doi:10.1016/0747-5632(93)90029-R.

Kitchakarn, Orachorn. 2015. "EFL Learners' Attitudes towards Using Computers as a Learning Tool in Language." TOJET: The Turkish Online Journal of Educational Technology 14 (2): 52-58. 
Liaw, Shu-Sheng, Weng-Cheng Chang, Wu-Hsiung Hung, and Hsiu-Mei Huang. 2006. "Attitudes toward search engines as a learning assisted tool: Approach of Liaw and Huang's research model." Computers in Human Behavior 22 (2): 177-190. doi: http://dx.doi.org/10.1016/j.chb.2004.09.003.

Liaw, Shu-Sheng, and Hsiu-Mei Huang. 2003. "An investigation of user attitudes toward search engines as an information retrieval tool." Computers in Human Behavior 19 (6): 751765. doi: http://dx.doi.org/10.1016/S0747-5632(03)00009-8.

Loyd, Brenda H., and Clarice Gressard. 1984. "Reliability and factorial validity of computer attitude scales." Educational and psychological measurement 44 (2): 501-505. doi: 10.1177/0013164484442033.

Mengual, Santiago. 2011. "La importancia percibida por el profesorado y el alumnado sobre la inclusión de la competencia digital en Educación Superior. Un análisis en Ciencias de la Actividad Física y el Deporte de la Universidad de Alicante." PhD diss., University of Alicante, Spain.

Mitra, Anandra. 1998. "Categories of computer use and their relationships with attitudes toward computers." Journal of Research on Computing in Education 30 (3): 281-296. doi:10.1080/08886504.1998.10782227.

Novo-Corti, Isabel, Laura Varela-Candamio, and María Ramil-Díaz. 2013. "E-learning and face to face mixed methodology: Evaluating effectiveness of e-learning and perceived satisfaction for a microeconomic course using the Moodle platform." Computers in Human Behavior 29 (2): 410-415. doi:10.1016/j.chb.2012.06.006

Oblinger, D. and Oblinger, J. 2005. "Is It Age or IT: First Steps Toward Understanding the Net Generation" In Educating the Net Generation, edited by Diana G. Oblinger and James L. Oblinger, 2.1-2.20. Washington, DC: EDUCAUSE.

Olvera-Lobo, María-Dolores, and Belarmina Benítez-de-Vendrell. 2008. “Aproximación a las actitudes y percepciones de los usuarios ante las tecnologías de la información." EI profesional de la información 17 (2): 199-204.

Park, Chanho, and Sookyung Cho. 2014. "The effects of Korean learners' online experiences on their English writing." TOJET: The Turkish Online Journal of Educational Technology 13 (3): 202-209. 
Perloff, Richard M. 2014. The dynamics of persuasion: communication and attitudes in the 21st century ( $5^{\text {th }}$ ed.). Nueva York, NY: Routledge.

Popovich, Paula M., Karen R. Hyde, Todd Zakrajsek, and Catherine Blumer. 1987. "The development of the attitudes toward computer usage scale." Educational and psychological measurement 47 (1): 261-269. doi: 10.1177/0013164487471035.

Raat, Jan H., and Marc de Vries. 1985. "What do 13-Year old pupils think about technology? the conception of and the attitude towards technology of 13-year old girls and boys." Paper presented at the Science and Technology Education and Future Human Needs Conference of the International Council of Scientific Unions, Bangalore, August 6-14.

Rex, Karsten, and Roberta M. Roth. 1998. "The relationship of computer experience and computer self-efficacy to performance in introductory computer literacy courses." Journal of Research on Computing in Education, 31 (1): 14-25. doi:10.1080/08886504.1998.10782238.

Richardson, Virginia. 1996. "The role of attitudes and beliefs in learning to teach." In Handbook of research on teacher education, edited by John Sikula, 102-119. Nueva York: Macmillan.

Rozell, Elizabeth J., and William L. Gardner. 2000. "Cognition, motivation, and affective processes associated with computer-related performance: A path analysis." Computers in Human Behavior 16, (2): 199-222. doi:10.1016/S0747-5632(99)00054-0.

Selwyn, Neil. 1997. "Students' attitudes toward computers: validation of a computer attitude scale for 16-19 education." Computers \& Education 28 (1): 35-41. doi:10.1016/S03601315(96)00035-8.

Smith, B., Peter Caputi, Nadia Crittenden, Rohan Jayasuriya, and Patrick Rawstorne. 1999. "A review of the construct of computer experience." Computers in Human Behavior 15 (2): 227-242. doi:10.1016/S0747-5632(99)00020-5

Šumak, Boštjan, Marjan Heričko, and Maja Pušnik. 2011. "A meta-analysis of e-learning technology acceptance: The role of user types and e-learning technology types." Computers in Human Behavior 27 (6) 2067-2077. doi:10.1016/j.chb.2011.08.005. 
Shaft, Teresa M., Mark P. Sharfman, and Wilfred W. Wu. 2003. "Reliability assessment of the attitude towards computers instrument (ATCI)." Computers in Human Behavior 20 (5): 661-689. doi:10.1016/j.chb.2003.10.021.

Topkaya, Ece ZEHIR. 2010. “Pre-service English language teachers' perceptions of computer selfefficacy and general self-efficacy." The Turkish Online Journal of Educational Technology 9 (1): 143-156.

Tretiakov, Alexei, and Kinshuk. 2008. "Towards Designing m-Learning Systems for Maximal Likelihood of Acceptance." International Journal of Engineering Education 24 (1): 7983.

Venkatesh, Viswanath. 1999. "Creation of favorable user perceptions: exploring the role of intrinsic motivation." MIS Quarterly 23 (2): 239-260. doi: 10.2307/249753.

Venkatesh, Viswanath, Michael G. Morris, Gordon B. Davis, and Fred D. Davis. 2003. "User acceptance of information technology: Toward a unified view." MIS Quarterly 27 (3): 425-478.

Waycott, Jenny, Sue Bennett, Gregor Kennedy, Barney Dalgarno, and Kathleen Gray. 2010. "Digital divides? Student and staff perceptions of information and communication technologies." Computers \& Education $54 \quad$ (4): 1202-1211. doi:10.1016/j.compedu.2009.11.006.

Wilkinson, Ann, Julia Robert, and Alison E. While. 2010. "Construction of an instrument to measure student information and communication technology skills, experience and attitudes to e-learning." Computers in Human Behavior 26 (6): 1369-1376. doi:10.1016/j.chb.2010.04.010.

Yu, Kuang-Chao, Kuen-Yi Lin, Feng-Nien Han, and I-Ying Hsu. 2012. "A model of junior high school students' attitudes toward technology." International Journal of Technology and Design Education 22 (4): 423-436. Doi: 10.1007/s10798-011-9154-8.

Zweekhorst, Marjolein B. M., and Jeroen Maas. 2015. "ICT in higher education: students perceive increased engagement." Journal of Applied Research in Higher Education 7 (1): 2-18. http://dx.doi.org/10.1108/JARHE-02-2014-0022. 